\title{
Como a Biologia Celular tem Sido Abordada por Revistas de Divulgação Científica
}

\author{
Carlos Alberto Andrade Monerat ${ }^{1}$ \\ Marcelo Borges Rocha²
}

\begin{abstract}
Resumo
Compreender a ciência como ela realmente se apresenta é uma condição importante para 0 entendimento dos processos pelos quais passa a natureza e, como parte dela, os organismos que nos cercam. Nisto, a educação científica assume certo protagonismo, e como parte da estratégia para aproximar o conhecimento científico das pessoas, a divulgação científica, por meio das mídias impressas, se constitui em um desses instrumentos. A Biologia Celular, por se tratar de um importante campo do conhecimento científico, deve ser apresentada de forma didática e contextualizada, para que sua compreensão aconteça e, assim, possa cooperar com o desenvolvimento dos campos científicos e tecnológicos de uma sociedade. Mediante uma pesquisa descritiva, este estudo objetivou analisar a linguagem utilizada nos textos de divulgação científica concernentes à Biologia Celular publicados em revistas de grande circulação. Foi possível identificar que existe considerável quantidade de publicações relacionadas à Biologia Celular nas revistas de divulgação científica, com ampla utilização de recursos linguísticos, como metáforas e analogias, evidenciando a importância da compreensão destas questões para que se ampliem as discussões no campo do ensino científico, além de contribuir como referencial teórico posto à disposição de educadores e pesquisadores, colaborando também para que seus conteúdos sejam compreendidos pelos leitores.
\end{abstract}

Palavras-chave: Recursos linguísticos. Mídia impressa. Ensino de Ciências.

1 Doutor em Ciência, Tecnologia e Educação do Laboratório de Divulgação Científica e Ensino de Ciências - Centro Federal de Educação Tecnológica Celso Suckow da Fonseca - Cefet/RJ. Docente do Centro Universitário Celso Lisboa e das Faculdades São José. Orcid: <http://orcid. org/0000-0001-7446-9889>. carlos.monerat@gmail.com

2 Doutor em Ciências Biológicas, docente do Programa de Pós-Graduação em Ciência, Tecnologia e Educação do Centro Federal de Educação Tecnológica Celso Suckow da Fonseca - Cefet/RJ, no Laboratório de Divulgação Científica e Ensino de Ciências. Orcid: <http://orcid.org/00000003-4472-7423>.rochamarcelo36@yahoo.com.br 


\title{
HOW CELL BIOLOGY HAS BEEN APPROACHED IN SCIENTIFIC DISCLOSURE MAGAZINES
}

\begin{abstract}
Understanding the science as it really presents itself is an important condition for the understanding of the processes through which the nature passes and as the part of it, the living beings that surround us. On this, the science education assumes certain role, and as part of the strategy to bring the people's scientific knowledge, the Scientific Disclosure, through the printed media, is one of these instruments. The Cell Biology, being an important field of scientific knowledge, must be presented in a didactic and contextualized way, so that its understanding happens and, thereby, can cooperate with the development of the scientific and technological fields of a society. Through a descriptive research, this study aimed to analyze the language used in scientific texts related to cell biology published in mass circulation magazines. Was possible to notice that exist a consider quantity of Cell Biology articles in Scientific Disclosure magazines, with large use of language resources, as metaphors and analogies, making it evident the importance to understanding of these questions to broaden the discussions at the field of scientific education, in order to contribute as theoretical reference made available to educators and researchers, collaborating for their contents be understood by readers.
\end{abstract}

Keywords: Language resources. Printed media. Science teaching.

Recebido em: 12/9/2017

Aceito em: 4/12/2017 
Os textos de divulgação científica devem contar com o envolvimento do leitor para transmitir a informação desejada. Nesse sentido, questões relacionadas ao grau de aprofundamento do tema a ser tratado, modos de abordagem dos conceitos mais complexos e as estratégias que devem ser utilizadas envolvem escolhas de recursos linguísticos apropriados para que a mensagem não seja deturpada e mantenha os objetivos da divulgação da ciência. Um exemplo é o uso, nos textos de divulgação, das explicações de conceitos científicos específicos, pois para o seu melhor esclarecimento, muitas vezes faz-se necessário o uso de metáforas, analogias, exemplos, desenhos esquemáticos, entre outros, bem como a correta inserção dessas explicações no texto, acompanhadas de uma adequada contextualização para que este texto cumpra com o seu objetivo, tendo em vista os fatores já mencionados.

Muitos pesquisadores em ensino e educação voltam parte da sua atenção às questões linguísticas, devido à grande importância no processo de construção da ciência e do conhecimento científico (ANDRADE; ZYLBERSZTAJN; FERRARI, 2002). Autores como Fredriksson e Pelger (2016) afirmam que, para uma sólida formação científica, a atenção dada à escrita de textos científicos deve acompanhar o estudante por toda a Graduação, sempre com a preocupação em fazer com que estes alunos desenvolvam continuamente a escrita científica, para que esta possa, além de chegar adequadamente aos seus pares, também atingir um maior número de pessoas, principalmente os leigos.

Neste contexto, a divulgação científica pode atuar como uma estratégia de aproximação entre o conhecimento científico e o público em geral, pois, de acordo com Valério e Bazzo (2006) esta deve ser compreendida como um instrumento no campo da comunicação a serviço da educação e das ciências. Isso posto, dentro deste entendimento, para auxiliar o processo de compreensão da ciência é necessário que sejam criadas oportunidades que permitam o desenvolvimento e o processamento das suas informações, mediante uma ação interativa que envolve processos textuais e linguísticos, permitindo que o leitor faça a relação das informações disponíveis no texto, conferindo sentido a elas (MENDONÇA, 2010; MORENO, 2008). 
Monteiro e Soares (2014), além de Kleiman (2000), comentam que, durante a leitura de um texto, duas atividades fundamentais são desenvolvidas pelo leitor: a identificação das palavras que compõem o texto e a construção dos significados para aquilo que está sendo lido. Para realizar a leitura de forma eficiente, no entanto, ele deve dar atenção a essas duas atividades igualmente.

A construção do significado se baseia em reunir as palavras lidas em unidades significativas de pensamento, permitindo que o leitor faça inferências, relacione informações prévias com as apresentadas no texto e analise criticamente o significado construído (MONTEIRO; SOARES, 2014, p. 451).

Em relação às informações científicas, a compreensão delas por parte de um determinado público muitas vezes não ocorre de forma simples, desse modo, a utilização de recursos textuais, com o objetivo de facilitar o seu entendimento, é de fundamental relevância para que o seu objetivo seja alcançado (FREDRIKSSON; PELGER, 2016). Assim sendo, de acordo com Pacheco (2008), as metáforas podem desempenhar bem esse papel, pois comunicam indiretamente, revelando-se um processo de linguagem que consiste em fazer uma substituição analógica de termos e palavras, desmistificando temas complexos e trazendo uma linguagem mais coloquial para aproximar o leitor das informações.

Para Yener e Özkadif (2010), metáforas e analogias são recursos que podem e devem ser utilizados para facilitar o entendimento de conceitos abstratos, permitindo o entendimento da escrita científica por um público leigo.

Rocha e Vargas (2015) definem as metáforas como sendo

[...] uma figura de estilo, que consiste numa comparação entre dois elementos por meio de seus significados imagísticos, causando o efeito de atribuição "inesperada" ou improvável de significados de um termo a outro. Didaticamente, pode-se considerá-la como uma comparação que não usa conectivo (por exemplo, "como"), mas que apresenta de forma literal uma equivalência que é apenas figurada (p. 6). 
O trabalho de Ferraz e Terrazzan (2001, p. 7) atribui uma definição para as analogias como: "ferramentas no processo de construção de noções científicas por aproximarem dois conceitos heterogêneos", realizando, segundo Santos, Terán e Silva-Forsberg (2011, p. 592), "essa ponte de transposição com o objetivo de mediar à compreensão e levar ao conhecimento do modelo processual historicamente proposto da Ciência". Por isso, as analogias e metáforas devem ser entendidas não só como uma relação de significações, de objetos e de fenômenos, mas também como pretendem descrever e penetrar na realidade biológica.

Mediante o anteriormente exposto, o objetivo deste trabalho concentrou-se em caracterizar recursos de linguagem utilizados, bem como erros e inconsistências conceituais existentes nos textos sobre Biologia Celular publicados em revistas de divulgação científica. A escolha pela Biologia Celular, por intermédio das revistas de divulgação científica, deve-se a sua importância como componente curricular dentro da Biologia, nos diferentes níveis de formação, além das suas potenciais contribuições na apropriação de saberes e conceitos científicos relativos a este campo da ciência. Também não se pode desconsiderar a sua relevância em diferentes segmentos da sociedade, fornecendo contribuições à saúde, ao ambiente e ao desenvolvimento tecnológico e industrial, além das inúmeras inovações científicas relacionadas à clonagem, ao estudo do genoma, do potencial das células-tronco nas suas diversas terapias, no desenvolvimento de fármacos, entre outros, como apontam Silva (2000), Legey, Jurberg e Coutinho (2009) e Gomes, Da Poian e Goldbach (2012).

\section{Desenho Metodológico}

O presente artigo baseia-se em uma pesquisa descritiva, a qual Gil (2008) aponta como sendo aquela que apresenta a utilização de técnicas padronizadas para reunir informações, por meio de uma observação sistemática do objeto de pesquisa. No caso específico deste trabalho, para a análise dos recursos de linguagem dos textos publicados foi escolhido o método da análise de conteúdo, que segundo Bardin (2009), traduz-se em um conjunto de técnicas de análise das comunicações que utiliza procedimentos sistemáticos e objetivos para a 
descrição do conteúdo das mensagens. Sob essa perspectiva, os procedimentos de análise organizaram-se ao redor de um processo de categorização. A categorização também pode ser entendida como a passagem de dados brutos a dados organizados, a partir de critérios definidos. A elaboração das categorias pode seguir dois caminhos distintos: as categorias criadas a priori e as criadas a posteriori. No presente estudo as categorias de análise seguiram a ótica do segundo caminho, uma vez que as categorias emergiram do conteúdo das reportagens selecionadas, e envolveram uma constante consulta à teoria. Esse processo pressupõe a elaboração de muitas versões do sistema de categorias criado, que, conforme vai sendo reelaborado, é lapidado e enriquecido para dar origem a uma versão final mais completa.

Para a presente investigação foi realizado um levantamento das revistas de divulgação científica de circulação nacional e que apresentavam regularidade nas suas publicações, com a possibilidade da abordagem de temas relacionados à Biologia Celular em suas matérias também sendo considerada. Dessa forma, as revistas contempladas foram Ciência Hoje, Galileu, Scientific American Brasil e Superinteressante.

O recorte temporal que pautou a escolha das revistas de divulgação científica para análise compreendeu o período entre janeiro de 2011 e dezembro de 2015. Este intervalo foi definido de forma arbitrária, porém levando em consideração uma quantidade considerável de publicações, haja vista que cada revista escolhida conta com edições mensais, destacando-se que uma delas, a revista Superinteressante, ainda possui edições especiais, sem, no entanto, contar com uma periodicidade regular no caso destas referidas edições.

$\mathrm{O}$ outro fator preponderante diz respeito à facilidade de acesso aos exemplares, a fim de selecionar conteúdos pertinentes à Biologia Celular para fazer parte do estudo. A busca foi realizada por meio dos acervos digitais e das edições impressas das revistas escolhidas para o desenvolvimento do trabalho.

Na verificação das revistas, por intermédio da leitura dos seus conteúdos para a seleção dos textos, foi feita uma catalogação com o objetivo de se constituir um banco de dados, compondo-se para esta etapa de uma abordagem quanti-qualitativa, a qual, segundo Minayo (2002), permite recolher mais in- 
formações do que se poderia conseguir isoladamente, uma vez que a pesquisa quantitativa centra-se na objetividade, influenciada pelo positivismo, com base na análise de dados brutos, coletados com o auxílio de técnicas padronizadas e neutras, e a pesquisa qualitativa não se preocupa com representatividade numérica, mas, sim, com o aprofundamento da compreensão de um grupo social ou de uma organização.

Desse modo, os textos relacionados à Biologia Celular trazidos nas revistas de divulgação científica escolhidas foram apurados e quantificados, revelando os seus totais e percentuais dentro do período pesquisado, juntamente com a produção de informações mais aprofundadas e elucidativas.

\section{Resultados e Discussão}

Para expressar os primeiros resultados da pesquisa torna-se importante ressaltar que foi identificada um considerável número de textos relacionados à Biologia Celular, publicados nas revistas escolhidas. Esta relevante quantidade está representada por 601 matérias publicadas, em um total de 273 exemplares analisados.

Foi apurada uma média geral de 2,2 artigos por revista, levando-se em consideração o período pesquisado, conforme os dados apontados na Tabela 1, revelando que, entre as reportagens exibidas, voltadas de um modo geral para aspectos da ciência e tecnologia, pouco mais de duas matérias são pertinentes à Biologia Celular.

Tabela 1 - Quantidade e média de textos encontrados nas revistas pesquisadas

\begin{tabular}{lcc}
\hline \multicolumn{1}{c}{ Revistas } & Matérias & Exemplares \\
\hline \hline Superinteressante & 143 & 98 \\
Galileu & 119 & 60 \\
Scientific American Brasil & 172 & 60 \\
Ciência Hoje & 167 & 55 \\
\hline \multicolumn{1}{c}{ Totais } & 601 & 273 \\
\hline Matérias por exemplar (média) & & 2,2 \\
\hline
\end{tabular}

Fonte: Os autores. 
A Scientific American Brasil foi a revista que mais apresentou matérias relacionadas à Biologia Celular no período pesquisado, contrastando com a Revista Galileu, que por sua vez teve o menor número de textos, conforme mostrado na Figura 1.

Figura 1 - Quantidade de textos encontrados por revista pesquisada

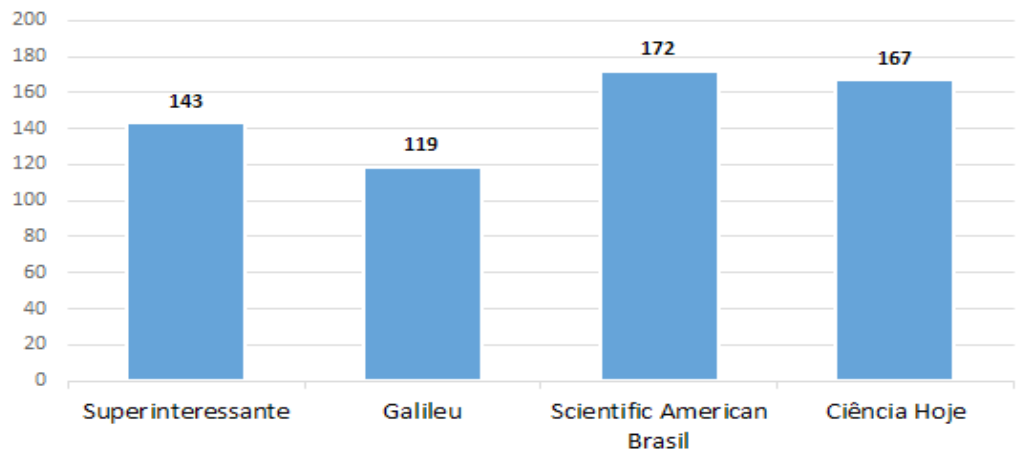

Fonte: Os autores.

A Figura 2 ilustra a contribuição proporcionada pelas revistas, individualmente, em relação ao total de textos publicados durante o período da pesquisa, salientando percentuais representativos ocupados pela Biologia Celular e seus temas correlatos. Esta representatividade se materializa quando, mediante uma breve consideração, percebe-se o fato de que ela deve repartir espaço com os demais temas científicos e tecnológicos, nestas que são revistas de grande abrangência, e que, além do aspecto científico, devem também se distinguir pela destinação comercial.

Legey, Jurberg e Coutinho (2009) demonstram que tal fato deve-se à importância do conhecimento sobre a Biologia Celular para a compreensão de conceitos e as suas possibilidades de aplicações práticas, como no sequenciamento do genoma de organismos diversos, nas terapias gênicas e com células-tronco, na elaboração de transgênicos, técnicas de clonagem, entre outros. 
Figura 2 - Percentual das matérias sobre Biologia Celular em relação ao total publicado

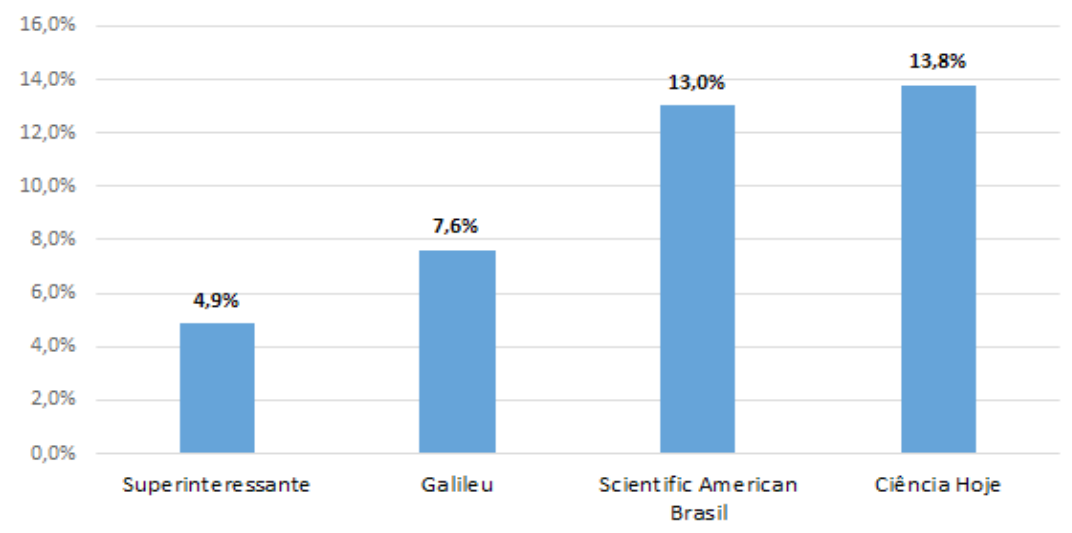

Fonte: Os autores.

Outros dados mostram ainda mais razões para esta notoriedade, que irá se refletir nos cuidados com o meio ambiente e, consequentemente, nos seus desdobramentos com a saúde e o bem-estar de todos. Esta ampla divulgação dos postulados da Biologia Celular também traz uma outra perspectiva no campo do ensino, da qual professores de Ciências e Biologia, nas mais variadas instâncias da Educação Básica e Superior, devem se inteirar, pois muitas vezes se traduzem como as fontes mais confiáveis de esclarecimento dos estudantes.

Com relação ao número total de exemplares publicados, as revistas Ciência Hoje e Scientific American Brasil são as que apresentam os maiores índices de matérias sobre Biologia Celular. Seus percentuais variam em torno de 13,8\% e $13 \%$ dos textos, respectivamente. Em uma análise que leva em consideração o estilo de cada revista, é possível que esta tendência deva-se às especificidades quanto aos temas estritamente científicos dos referidos periódicos em relação aos demais pesquisados (Galileu e Superinteressante), uma vez que estes últimos revelam um caráter mais generalista e comercial, abrangendo um conteúdo mais universalizado, pois volta-se a um perfil mais diversificado de público. 


\section{Figuras de Linguagem Empregadas: a utilização de analogias e metáforas nos textos}

Como parte das primeiras análises foram percebidas diferenças entre o estilo de redação que caracterizou os textos publicados. A partir dessas percepções foram categorizados dois grupos distintos, envolvendo duas revistas em cada grupo, de acordo com as diferenças na linguagem e com o tratamento textual adotado em cada perfil de revista, conforme relacionado na Tabela 2.

Tabela 2 - Comparativo entre os estilos textuais das revistas

\begin{tabular}{|c|c|}
\hline \multicolumn{2}{|c|}{ Características Textuais } \\
\hline Galileu/Superinteressante & Ciência Hoje/Scientific American \\
\hline Total acessibilidade textual & Moderadamente acessível textualmente \\
\hline Praticamente nenhum termo técnico e científico & Vários termos técnicos e científicos \\
\hline $\begin{array}{l}\text { Procedimentos explicativos e aproximações } \\
\text { com o cotidiano, demonstrando traços de } \\
\text { laicidade }\end{array}$ & $\begin{array}{r}\text { Explicações mais técnicas e pouca } \\
\text { aproximação com o cotidiano, demonstrando } \\
\text { traços de cientificidade }\end{array}$ \\
\hline $\begin{array}{l}\text { Não são necessárias definições para as } \\
\text { expressões }\end{array}$ & Recurso da definição usado com frequência \\
\hline Aspeamento escasso & Frequência do aspeamento \\
\hline Frequente emprego de conotações metafóricas & Moderado emprego de conotações metafóricas \\
\hline Frequente interlocução direta com o leitor & Alguns casos de interlocução direta com o leitor \\
\hline
\end{tabular}

Fonte: Os autores.

As Revistas Superinteressante e Galileu, com poucas variações entre ambas, caracterizam-se por possuírem uma linguagem acessível à maioria das pessoas, mesmo para aqueles que não têm contato com os pressupostos científicos, seja por formação ou interesse. Os termos utilizados não possuem complexidade para o seu adequado entendimento, pois buscam a aproximação com o cotidiano, mostrando traços de laicidade.

O uso de analogias e metáforas emergiu igualmente nos seus textos, pois com muita frequência estes periódicos fazem uso destes recursos para tornar os assuntos tratados mais claros e até mais atraentes para os leitores. Essas metáforas aparecem de diferentes maneiras nestas revistas, seja por meio de comparações e até por histórias. 
A título de exemplo, no artigo "Cientistas criam bactéria que come o $\mathrm{CO} 2$ do ar" (SUPERINTERESSANTE, edição 318, maio 2013), o próprio título já leva o leitor a pensar no uso da palavra "come" para representar o consumo do gás pelos organismos procariontes em questão. Nesse ponto fica claro o sentido metafórico utilizado pelo autor, posto que pela definição do Dicionário Escolar da Língua Portuguesa da Academia Brasileira de Letras, o verbo "comer" tem como o primeiro, de uma lista de significados: "Introduzir na boca, mastigar e engolir" (ACADEMIA..., 2008, p. 325). Certamente, o leitor com um mínimo conhecimento científico, mais precisamente de Biologia Celular, percebe que a célula bacteriana não conta com estruturas de tamanha complexidade estrutural para realizar o ato de "comer" qualquer coisa que seja.

$\mathrm{Na}$ mesma matéria o autor, juntamente com a linguagem metafórica, também se utiliza de uma elocução bem mais elaborada e de não tão clara compreensão para muitos. É o que se constata no seguinte trecho: "Depois de comer o gás, ele excreta ácido 3-hidroxipropiônico - que serve para fazer acrílico e é um dos compostos mais usados na indústria química”. O nome do ácido em questão não é algo corriqueiro, exceto para aquelas pessoas ligadas à Química. O presente artigo ainda utiliza termos como "transgênica”, explicando este significado parágrafos antes: "Numa experiência feita pela Universidade da Geórgia, nos EUA, esse micróbio recebeu cinco genes de outra bactéria subaquática, a Metallosphaera sedula. E dessa mistura saiu uma criatura capaz de algo muito útil: alimentar-se de CO2". Nota-se que o nome científico do outro microrganismo envolvido no processo foi grafado corretamente.

Ainda na revista Superinteressante, na edição especial 305a, em junho de 2012, na matéria com o título "Super homens sob medida", no trecho "A alteração surge na divisão celular. São células que não param de se dividir, que não querem morrer, querem continuar jovens" é utilizada uma metáfora para explicar o processo de continuação e descontrole da multiplicação celular, referindo-se a uma suposta "vontade" das células em continuar se reproduzindo, com os termos "não querem morrer, querem continuar jovens". 
$\mathrm{Na}$ revista Galileu o processo é bem parecido em termos de redação de matérias com o uso de metáforas, conforme visto na edição $n^{\circ} 236$, de março de 2011, no artigo intitulado: "Quem não aguenta bebe Leite Medicinal - Vacas transgênicas farão bebidas com remédios". Neste caso, já no subtítulo, o redator sinaliza que a reportagem será permeada por metáforas, por meio do trecho em que diz que a vaca "fará" do seu leite um medicamento, porém a aplicação da metáfora é pouco vista no conteúdo da matéria, e durante a leitura, o autor tenta esclarecer, meio que de forma superficial, como é desenvolvido o processo:

[...] cientistas da Universidade Norte do Paraná (Unopar) planejam outra revolução do mundo bovino: clonar animais transgênicos capazes de produzir leite com substâncias medicinais, como pré-insulina e hormônio do crescimento (GH), componentes para remédios para diabéticos e problemas de desenvolvimento físico, por exemplo. "As vacas leiteiras clonadas e transgênicas são mais eficientes na produção dessas proteínas medicinais do que as bactérias, suas grandes fabricantes atualmente", diz o biólogo e doutor em produção animal Paulo Roberto Adona, coordenador do projeto na Unopar. "Dezenas de litros de leite contendo as substâncias podem ser fornecidos diariamente", afirma Adona (REVISTA GALILEU, edição n. 236, mar. 2011).

Na revista Galileu, edição 285, de abril de 2015 o trecho da reportagem "O câncer no alvo da genética", em que relata "Infelizmente, células 'do bem' também são mortas, e o paciente pode sofrer diversos efeitos colaterais". As células saudáveis e de defesa são, de acordo com a analogia, as células "do bem", as quais seriam mortas pelo tratamento, gerando os tais efeitos colaterais.

Tais elementos do texto são importantes para sua compreensão, pois conforme relata Pacheco (2008, p. 21), "os componentes das metáforas precisam guardar uma relação que ofereça sentido para quem lê", sendo considerada um dos valiosos instrumentos utilizados pelos jornalistas científicos, pois dão espaço para o entendimento, excedendo o significado estritamente literal e favorecendo a compreensão.

As revistas Ciência Hoje e Scientific American Brasil, com uma tendência maior para a segunda, são as que mais apresentam textos com relativa complexidade da linguagem utilizada no corpo textual, em especial pela sua 
densidade lexical. Apesar, no entanto, de os seus artigos apresentarem uma linguagem mais elaborada, com grande quantidade de termos e expressões de cunho científico/tecnológico e, mais especificamente, biológico, elas também produzem artigos apoiados na utilização de metáforas e analogias, buscando uma maior aproximação com o leitor.

A matéria da revista Scientific American Brasil, na edição 119, de abr/2012, traz a matéria intitulada "Motoristas do Banco Traseiro", em que é utilizada a metáfora no título do artigo para evidenciar o papel da microbiota presente nos organismos na cadeia evolutiva das espécies. No texto é explicado que apesar de essas bactérias exercerem uma atividade secundária nos organismos dos quais participam, sem nem mesmo serem percebidas, são elas que terão participação decisiva em direcionar os rumos do processo evolutivo.

Nesta mesma edição da Scientific American Brasil consta um artigo de destaque, intitulado "O que torna o seu cérebro singular", o qual procura informar ao leitor sobre os processos que fazem do cérebro um órgão surpreendente e único em termos funcionais, mesmo no caso de gêmeos idênticos. Durante o desenvolvimento do texto é mostrada a interação dos genes na atividade dos neurônios por meio de um quadro ilustrativo com o tema "Genética Copie e Cole", fazendo uma clara analogia com o processo de transcrição de uma sequência do DNA, em que consta uma determinada informação genética para uma molécula de RNA mensageiro, e esta, por sua vez, desloca-se para o citoplasma objetivando a produção de uma proteína específica, transferindo essa informação para um ribossomo. O termo "Copie" faz uma analogia à transcrição da informação para o RNA e o termo "Cole" quando o RNA deixa a informação no ribossomo.

A revista Ciência Hoje apresenta linguagem moderadamente acessível, com certa frequência no emprego de alguns termos técnicos, no entanto a densidade desses termos busca ser amenizada com a presença de explicações e tentativas de aproximação com o cotidiano do leitor, manifestando claros traços de laicidade. As mesmas características encontram-se presentes no trabalho de Ferreira e Queiroz (2011). 
A publicação também recorre ao uso de metáforas, conforme verificado na edição 296, de setembro 2012, no artigo “Kamikazes altruístas”, em que o termo "Kamikaze" refere-se, segundo o Dicionário Escolar da Língua Portuguesa da Academia Brasileira de Letras, ao piloto de aviões da força aérea japonesa, que na $2^{\text {a }}$ Guerra Mundial era lançado, cheio de explosivos, contra alvos inimigos. Esta é uma referência à doença do sono, quando se descobriu que os primeiros parasitas invasores, o Trypanosoma brucei, agente causador da doença, produzem uma proteína chamada adenilatociclase, que permite que os primeiros tripanossomas da infecção, enquanto são atacados e destruídos, envenenem a primeira onda de células da resposta imune, o que garante o sucesso dos parasitas que vêm depois, numa clara alusão aos pilotos que se sacrificavam em combate.

O Trypanosoma brucei, agente causador da doença do sono, é conhecido por sua capacidade de se esquivar do ataque do sistema imune, o que torna o desenvolvimento de uma vacina um processo difícil. Agora, pesquisadores da Universidade Federal do Rio de Janeiro (UFRJ), em colaboração com as universidades Livre de Bruxelas (ULB), na Bélgica, e Ludwig Maximilians, de Munique, na Alemanha, descobriram uma nova ferramenta do parasita para garantir o sucesso da infecção: uma proteína chamada adenilatociclase. Ela permite que os primeiros tripanossomas da infecção, enquanto são destruídos, envenenem a primeira onda de células da resposta imune, garantindo o sucesso dos parasitas que vêm depois. A descoberta foi publicada na revista científica norte americana Science (REVISTA CIÊNCIA HOJE, edição 296, set. 2012).

\section{Erros Conceituais e Inconsistências Relacionados aos Textos}

Das revistas analisadas, a Superinteressante foi a que mais incorreu em situações nas quais as matérias publicadas apresentaram erros e inconsistências conceituais. Como exemplo, em sua edição 288, de fevereiro de 2011, ao divulgar um texto sobre as modificações ocorridas no corpo em situações de risco, poderia utilizar a nomenclatura apropriada ao citar os nomes das estruturas celulares, por exemplo, no caso das "miofibras", que poderiam dar lugar ao termo miofibrilas ou miócitos, que estariam mais adequados. 
Ainda em relação às "miofibras" citadas na reportagem, uma vez representando as células musculares, estas não são apenas "Compostas de proteínas" como leva a entender, de forma ambígua, a redação do texto.

\section{Força e resistência}

Mesmo que por um curto período, nossos músculos são capazes de se contrair todos de uma vez, gerando uma força incomum. Com endorfina, é possível não sentir dor, e os ossos modificam sua estrutura para suportar grandes pressões.

Músculos

\section{OXIGENADO}

Com a adrenalina no corpo, o sangue circula com mais facilidade e intensidade, levando mais oxigênio aos músculos, que passam a trabalhar mais contraídos.

\section{PODER DA MENTE}

Por isso, quando o sistema nervoso envia os impulsos elétricos para estimular os músculos, as fibras de contração rápida são ativadas todas simultaneamente.

\section{RICOS EM FIBRAS}

Tudo ocorre a um nível microscópico: cada músculo tem milhares de fibras, que contêm centenas de miofibras.

\section{CONTRAIR E COÇAR}

Compostas de proteínas, as miofibras são formadas por filamentos menores ainda. Esse conjunto provoca a contração muscular depois de receber o impulso elétrico.

\section{ENCAIXE PODEROSO}

Os filamentos são dispostos em fileiras. Na contração muscular, um desliza sobre o outro e eles se encaixam é dessa sincronia que vem a explosão de força (REVISTA SUPERINTERESSANTE, edição 288, fev. 2011, p. 37).

As informações também poderiam estar mais completas quanto ao relato do processo de contração muscular, sem, no entanto, confundir o leitor com termos complexos, pois conforme relatado em tratados de Fisiologia Humana, por Guyton e Hall (2006), os músculos são compostos por numerosas fibras. Cada uma dessas fibras é formada por centenas a milhares de miofibrilas. Cada 
miofibrila é também composta por filamentos de miosina e de actina, que são longas moléculas de proteínas, além de uma membrana e um revestimento de uma fina camada de material polissacarídeo.

Tais informações, como expostas na matéria, não causariam muita confusão ao leitor, desde que este já possuísse um grau de compreensão, pelo menos, ao nível do Ensino Médio, uma vez que o conteúdo deixou de fornecer a denominação correta dos componentes celulares em questão, aglutinando por demais o tema proposto.

Mais um exemplo de erro conceitual na Revista Superinteressante acontece na edição 297, de novembro de 2011, quando uma matéria se propõe a relatar uma série de sintomas do organismo quando se leva um susto: "O quê? Aumento de pressão do sangue. Por quê? Junto com constrição de vasos e coração acelerado, transporta rapidamente energia, aumenta a circulação e evita hemorragias" (REVISTA SUPERINTERESSANTE, edição 297, nov. 2011).

O transporte de energia acontece ao nível celular, não sendo a corrente sanguínea determinante para esse transporte. Quando a circulação é aumentada, o risco de hemorragia não é evitado. Pelo contrário, esta tem mais chances de acontecer, uma vez que o sangue está mais intensamente atuando em diferentes pontos do organismo.

Na edição 298, de dezembro de 2011, na matéria "Tratamento pode reverter a síndrome de Down”, o título do texto não levou em consideração o teor da reportagem, em que é tratado o processo de reversão, baseado apenas nos aspectos cognitivos da síndrome, e que o fenótipo do indivíduo permaneceria o mesmo, contrariando, assim, o título do artigo, dado que a síndrome de Down não seria revertida inteiramente, levando em consideração tanto nos seus aspectos genotípicos quanto em termos fenotípicos.

A Superinteressante, dessa vez na edição especial 305A, de junho de 2012, na matéria intitulada "Somos todos mutantes" é percebido um erro conceitual no trecho: "Lembra dos nucleotídeos, as letras A, T, C e G que formam o gene? São 6 bilhões delas em cada célula do corpo, metade herdada do pai, e outra, da mãe". Neste caso há uma confusão na utilização do termo nucleotídeo, que, segundo De Robertis, Hib e Ponzio, (2008), Campbell et al. (2010), Amabis 
e Martho, (2012), Junqueira e Carneiro, (2012) e Linhares e Gewandsznajder, (2014), refere-se a polímeros constituídos por um fosfato (mais especificamente, ácido fosfórico), uma molécula de açúcar com cinco carbonos (pentose) e uma base nitrogenada. No caso do DNA, o açúcar referido trata-se da desoxirribose. No caso das "letras A, T, C e G”, estas são as bases nitrogenadas (compostos cíclicos que contêm nitrogênio), que podem ser púricas, representadas pela adenina (A) e guanina (G), ou pirimídicas, representadas pela timina (T) e citosina (C).

Outro erro conceitual encontrado na Superinteressante diz respeito à matéria publicada na edição 306, de julho de 2012, com o título: "Pegar friagem provoca resfriado?", em que o artigo tenta esclarecer um tema controverso, uma vez que muitas pessoas costumam associar um fato ao outro. Uma série de incoerências, no entanto, pode provocar uma confusão no leitor, a começar pelo trecho complementar ao título, em que se lê: "Quem causa a doença são vírus, e não o termômetro. O que acontece é que esses microorganismos (sic) estão mais ativos no inverno". No decorrer do texto as incorreções também continuam, como no trecho: "Mas é porque os vírus que causam problemas respiratórios estão mais ativos nessa época do ano. É a mesma coisa que o vírus da dengue. Ele está à toda no verão, porém ninguém fala que é o calor que provoca a doença".

É importante esclarecer que os vírus da gripe não têm maior atividade no inverno, tampouco o da dengue no verão. De acordo com Abbas e Lichtman (2008) e Tortora, Funke e Case (2012), os vírus não têm atividade metabólica própria, ao contrário das células vivas, como as bactérias, os protozoários, os fungos, entre outros, portanto não se trata de variações sazonais. $\mathrm{O}$ vírus da dengue não fica mais ativo no verão, porém os mosquitos, que são os seus vetores, encontram melhores condições de vida e, consequentemente, de reprodução nesta estação, e não que o vírus tenha maior atividade neste período. Da mesma forma quanto ao vírus da influenza: acredita-se que seja mais prevalente no inverno porque as pessoas tendem a ficar mais próximas e em ambientes mais fechados, e não devido a uma atividade (metabolismo) que os vírus não apresentam fora das células. 
Ainda na edição 306, de julho de 2012, com o título "Felicidade é definida pelos genes de cada um", um estudo propôs-se a identificar o que mais influenciaria na felicidade de uma pessoa, se as experiências que ela tem durante a vida ou as características previamente escritas em seu código genético. Nesse texto, as informações não aparecem de forma completa, faltando descrever de uma forma mais abrangente as análises comparativas dos resultados, pois, para se afirmar, em termos genéticos, que um aspecto se sobrepõe a outro, os autores precisariam ter colhido outros dados e amostras, como de irmãos gêmeos que viveram em ambientes distintos. Então, como se pode inferir que o aspecto ambiental é menos importante que o aspecto genético, se a pesquisa só colheu dados de pessoas num mesmo ambiente? Na matéria também não é mencionado onde foi publicado tal estudo.

Diante do mencionado, percebe-se que a Revista Superinteressante, devido ao seu apelo de mercado, possui um público variado, com maior direcionamento ao público jovem, o que é observado em relação à forma como os temas científicos são abordados, por meio dos títulos atraentes dado aos artigos. Nota-se também, claramente, que os títulos das matérias possuem um objetivo de entretenimento e atração, mantendo uma tendência da revista, que é tentar passar ao leitor a ideia de que o "conhecimento é a coisa mais divertida do mundo", porém é importante frisar que estão presentes na revista relatos que fogem da verdadeira essência da divulgação científica.

Outra constatação feita em relação aos erros conceituais foi que em alguns casos não há sequer a comprovação do estudo noticiado ou alguma referência sobre o texto. Há de se destacar também que determinadas matérias fazem alusão a pesquisas realizadas em apenas uma instituição, por meio de tão somente uma pessoa ou um grupo apenas de pesquisadores, o que vai de encontro com os pressupostos a respeito dos consensos sobre a natureza da ciência, resultando em uma visão distorcida e ingênua dos fatos e da atividade científica, o que interfere na compreensão pública da ciência ou popularização da cultura científica e tecnológica e, tal qual, deturpa os princípios da divulgação científica. Na opinião de Vázquez-Alonso et al. (2008), estando as pessoas mais 
informadas sobre ciência e tecnologia, melhor saberão como estas afetam o seu cotidiano, viabilizando o surgimento de opiniões mais rigorosas sobre o tema, as tomadas de decisão e melhores contribuições como cidadãos para a sociedade.

As analogias, da maneira como estavam inseridas nas publicações, incorreram no risco de serem interpretadas como conceitos. Rocha e Vargas (2015) destacam a valorização excessiva da analogia para explicar fatos e conceitos científicos, aliada à não utilização de um raciocínio analógico por parte do público leitor como potenciais riscos à precisão conceitual e inadequada apropriação das informações publicadas em textos de divulgação científica.

Quanto às metáforas, o seu uso indevido pode incidir em um possível problema epistemológico, dado que, para Nascimento (2005), nem sempre as ideias equivocadamente formadas por meio da sua utilização são passageiras, influenciando na formação do espírito científico e do pensamento autônomo dos indivíduos.

Observou-se também que as revistas incidem mais em erros conceituais ou incoerências nos textos quando enveredam para assuntos com perfis aleatórios, envolvendo entretenimento e/ou curiosidades. Apesar disso, ainda é possível o uso didático de alguns desses textos, porém isto exigirá escolhas cuidadosas, além de um trabalho mais atento com alunos, mediante uma leitura atenciosa e crítica quanto à presença de manchetes sensacionalistas, evitando-se generalizações antecipadas e a construção de conceitos incorretos e sem fundamento.

\section{Considerações Finais}

Cada uma das revistas de divulgação científica pesquisadas apresenta uma quantidade considerável de textos relacionados à Biologia Celular, trazendo um vasto material que mostra a valorização do conhecimento biológico atual e, mais ainda, encontra possibilidades de auxiliar o desenvolvimento de uma cultura científica. 
Desse modo, os temas e questões relacionadas à Biologia Celular que a mídia impressa aborda por meio das suas publicações em revistas de divulgação científica, além das suas potenciais contribuições na apropriação de saberes e conceitos científicos relativos a este campo da ciência, se faz um interessante objeto de estudo, que naturalmente pode se desdobrar em questionamentos no sentido de analisar o que vem sendo divulgado sobre Biologia Celular e as suas possíveis utilizações junto a estudantes. Sendo assim, o uso de materiais, como os de divulgação científica, pode se constituir em alternativas úteis em sala de aula.

Muitos dos textos publicados apresentam uma linguagem clara e objetiva, porém nem todas as matérias seguiram o mesmo padrão. Pela lógica, este modelo está atrelado à tônica de redação escolhida para compor o perfil de cada uma delas, por isso torna-se importante uma sistematização dos recursos textuais como parâmetro para se determinar a elaboração da linguagem dos artigos.

$\mathrm{Na}$ análise dos textos fica constatada a ampla utilização de figuras de linguagem, como metáforas e analogias, tornando evidente a importância de se tecer um paralelo entre estas, para que se compreenda o seu sentido mais amplo. Em relação ao alcance desta investigação, foi possível observar que a utilização destes recursos de linguagem nas revistas teve como objetivo despertar o interesse do público-leitor a respeito do conhecimento sobre os aspectos científicos e sobre o que é costumeiramente mostrado na literatura técnica, porém com uma linguagem mais acessível, transformando-as em canais de comunicação entre cientistas e leitores, situação tipicamente caracterizada na divulgação científica.

Tal constatação encontra respaldo em Bueno (2010), que aponta a divulgação científica, por meio do jornalismo científico, como aquela que deve buscar formas de tornar essa apropriação das informações sobre ciência cada vez mais compreensível e próxima das pessoas, mediante linguagens acessíveis e estratégias adequadas, devendo constituir-se em um dos seus principais objetivos no que respeita à disseminação da informação científica.

Por isso, embora seja notória a importância da utilização recorrente de figuras de linguagem nos textos de divulgação científica, torna-se imprescindível o cuidado a ser observado para que estas estratégias não incorram em erros ou 
incoerências na transmissão da informação, caso contrário o processo de transmissão dos conceitos científicos seguirá o caminho completamente inverso ao dos princípios da divulgação da ciência.

Conforme alertado por Andrade, Zylbersztajn e Ferrari (2002), no entanto, para não incidir em aspectos que não apresentam correspondência entre si e perder a sua utilidade para compreensão dos conceitos científicos, o uso de analogias e metáforas nos textos deve primar pelo cuidado quanto à forma de abordagem, evidenciando uma preocupação com as características da utilização do conceito que é mais familiar para se pensar sobre o conceito que se pretende ensinar.

Outro fato observado durante a análise dos textos diz respeito a determinados conteúdos, em algumas das revistas analisadas, apresentarem erros conceituais e algumas incoerências. Nenhum destes acontecimentos, entretanto, chegou a prejudicar a essência e a ideia a serem transmitidas aos leitores, por não afetarem o seu correto entendimento. É importante frisar, porém, que, dependendo do grau de maturidade deste leitor, o seu conhecimento pode ser influenciado pela imprecisão de tais informações, prejudicando a maneira como esta pessoa vai se apropriar daquele conteúdo.

Quanto a isso, Albagli (1996) ressalta a importância do cuidado em se transmitir a informação, pois as incoerências podem conduzir a um caminho contrário ao dos princípios da divulgação científica, que é levar à sociedade a percepção verdadeira da atividade científica e assimilação de seus resultados, a partir dos tipos e canais de informação científica a que tem acesso. Mediante um maior cuidado nas reelaborações discursivas, os textos em questão poderiam trazer explicações mais detalhadas dos temas científicos abordados, explorando melhor os pontos importantes sem, no entanto, cair na complexidade do tecnicismo, e também sem incorrer em ocultações de informações fundamentais ou em equívocos conceituais.

A utilização de metáforas e analogias na ciência extrapola a intenção de se usá-las somente objetivando comparações para simplificar determinadas questões. Essas figuras de linguagem revelam-se úteis em diversas situações, seja porque abreviam uma descrição, seja porque resumem um pensamento, 
colocando o leitor a par do que se quer transmitir. Por isso, uma das áreas das Ciências em que as figuras de linguagem aparecem frequentemente nas revistas pesquisadas é na Biologia Celular. Este fato pode acontecer, talvez, pela complexidade dos seus temas correlatos, fazendo com que os responsáveis pelas matérias lancem mão de alguns recursos, como as metáforas e as analogias, para atingir melhor o público.

Por meio dessa análise foi possível constatar que as figuras de linguagem são utilizadas em diversas áreas do conhecimento científico e também em várias outras áreas do conhecimento. Com as revistas de divulgação científica pesquisadas não foi diferente: esse recurso foi empregado objetivando traduzir, mediante informações mais claras e acessíveis, o conhecimento científico que estava impresso nos textos, e as metáforas e analogias auxiliaram eficientemente nesse processo de compreensão, uma vez que seus conteúdos puderam ser transformados.

Pesquisadores como Palmero (1997), além de Knippels, Waarlo e Boersma (2005), perceberam que determinados critérios na colocação de textos científicos que trazem relação com compêndios biológicos são necessários para o seu entendimento. Desse modo, este trabalho destaca que a compreensão destas questões poderá ampliar a discussão no campo do ensino científico, no intuito de contribuir como referencial teórico posto à disposição de educadores e pesquisadores. $O$ contexto trazido pela divulgação científica, todavia, poderá colaborar diretamente para que a assimilação dos conteúdos de Biologia Celular possa ocorrer de forma satisfatória, pois o seu aprendizado não se dá de forma diferente dos demais processos de aprendizagem, em comparação com quaisquer outros conteúdos da área científica.

\section{Referências}

ABBAS, A. K.; LICHTMAN, A. H. Cellular and Molecular Immunology. 6. ed. Londres: Elsevier, 2008.

ACADEMIA BRASILEIRA DE LETRAS (ABL). Dicionário escolar da língua portuguesa. 2. ed. São Paulo: Companhia Editora Nacional, 2008. 
ALBAGLI, S. Divulgação Científica: informação científica para a cidadania? Revista Ciência da Informação, v. 25, n. 3, p. 396-404, 1996.

AMABIS, J. M.; MARTHO G. R. Biologia: biologia das células. 3. ed. São Paulo: Moderna, 2012. Vol. 1.

ANDRADE, B. L. de; ZYLBERSZTAJN, A.; FERRARI, N. As analogias e metáforas no ensino de ciências à luz da epistemologia de Gaston Bachelard. Revista Ensaio: Pesquisa em Educação em Ciências, v. 2, n. 2, p. 182-192, 2002.

BARDIN, L. Análise de conteúdo. 1. ed. Lisboa: Edições 70, 2009.

BUENO, W. C. Comunicação científica e divulgação científica: aproximações e rupturas conceituais. Informação \& Informação, v. 15, n. 1 (esp.), p. 1-12, 2010.

CAMPBELL, N. A. et al. Biologia. 8. ed. Porto Alegre: Artmed, 2010.

DE ROBERTIS, JR.; HIB, J.; PONZIO, R. De Robertis: Biologia celular e molecular. 14. ed. Rio de Janeiro: Guanabara Koogan, 2008.

FERRAZ, D. F.; TERRAZZAN, E. A. O uso de analogias como recurso didático por professores de biologia no ensino médio. In: ENPEC - ENCONTRO NACIONAL DE PESQUISA EM EDUCAÇÃO EM CIÊNCIAS 3. Atas... Atibaia: Abrapec - Associação Brasileira de Pesquisa em Educação em Ciências, 2001.

FERREIRA, L. N. de A.; QUEIROZ, S. L. Artigos da revista Ciência Hoje como recurso didático no ensino de química. Química Nova, v. 34, n. 2, p. 354-360, 2011.

FREDRIKSSON, A.; PELGER, S. Metaphorical concepts in molecular biology students' texts - a way to improve subjectmatter understanding. Nordina. v. 1, n. 12, p. 90-106, 2016.

GIL, A. C. Como elaborar projetos de pesquisa. 4. ed. São Paulo: Atlas, 2008.

GOMES, M. C.; DA POIAN, A. T.; GOLDBACH, T. Revistas de divulgação científica no ensino de ciências e biologia: contribuições e limitações de seu uso. In: ENECiências - ENCONTRO NACIONAL DE ENSINO DE CIÊNCIAS DA SAÚDE E DO AMBIENTE, 3. Niterói, RJ, 2012.

GUYTON, A. C.; HALL, J. E. Tratado de fisiologia médica. 11. ed. Rio de Janeiro: Elsevier, 2006.

JUNQUEIRA, L. C.; CARNEIRO, J. Biologia celular e molecular. 9. ed. Rio de Janeiro: Guanabara Koogan, 2012.

KLEIMAN, A. Texto e leitor: aspectos cognitivos da leitura. 2. ed. Campinas: Pontes, 2000.

KNIPPELS, M. C. P. J.; WAARLO, A. J.; BOERSMA, K. T. Design criteria for learning and teaching genetics. Journal of Biological Education, v. 39, n. 3, p. 108-112, 2005. 
LEGEY, A. P.; JURBERG, C.; COUTINHO, C. M. L. M. Educação científica na mídia impressa brasileira: avaliação da divulgação de biologia celular em jornais e revistas selecionados. Alexandria Revista de Educação em Ciência e Tecnologia, v. 2, n. 3, p. 35-52, 2009.

LINHARES, S.; GEWANDSZNAJDER, F. Biologia hoje. 2. ed. São Paulo: Ática, 2014.

MENDONÇA, H. R. A Importância da intertextualidade e da informatividade na formação dos leitores: a aquisição dos sentidos no veículo "jornal” em três gêneros distintos - a crônica, a notícia e a charge. Signum: Estudos da Linguagem, Londrina, v. 2, n. 13, p. 295-314, 2010.

MINAYO, M. C. de S. Ciência, técnica e arte: o desafio da pesquisa social. In: MINAYO, M. C. de S. et al. (Org.). Pesquisa social: teoria, método e criatividade. 21. ed. Petrópolis: Ed. Vozes, 2002.

MONTEIRO, S. M.; SOARES, M. Processos cognitivos na leitura inicial: relação entre estratégias de reconhecimento de palavras e alfabetização. Educação e Pesquisa, São Paulo, v. 40, n. 2, p. 449-466, 2014.

MORENO, T. de J. G. O conhecimento prévio e a referenciação na atividade de leitura. 2008. Dissertação (Mestrado em Língua Portuguesa) - Pontifícia Universidade Católica de São Paulo, São Paulo, 2008.

NASCIMENTO, T. G. Contribuições da análise do discurso e da epistemologia de Fleck para a compreensão da divulgação científica e sua introdução em aulas de ciências. Ensaio: Pesquisa em Educação em Ciências, v. 1, n. 2, p. 1-18, 2005.

PACHECO, C. G. As metáforas no jornalismo científico - análise das revistas Superinteressante e Galileu. Revista Eletrônica Temática, a. IV, n. 8, p. 1-32, 2008. Disponível em: <http://www.insite.pro.br/2008/23.pdf>.

PALMERO, M. L. R. Revisión bibliográfica relativa a la enseñanza/aprendizaje de la estructura y del funcionamiento celular. Investigações em Ensino de Ciências, v. 2, n. 2, p. 123-149, 1997.

ROCHA, M. B.; VARGAS, M. Estudo da linguagem de textos de divulgação científica. In: ENPEC - ENCONTRO NACIONAL DE PESQUISA EM EDUCAÇÃO EM CIÊNCIAS, 10., 2015, Águas de Lindóia. Atas... Águas de Lindóia: Abrapec - Associação Brasileira de Pesquisa em Educação em Ciências, 2015.

SANTOS, S. C. S.; TERÁN, A. F.; SILVA-FORSBERG, M. C. Analogias em livros didáticos de biologia no ensino de zoologia. Investigações em Ensino de Ciências, v. 15, n. 3, p. 591-603, 2011.

SILVA, L. H. P. Ciências biológicas e biotecnologia: realidades e virtualidades. São Paulo em Perspectiva, v. 14, n. 3, p. 60-67, 2000. 
TORTORA, G. J.; FUNKE, B. R.; CASE, C. L. Microbiologia. 10. ed. São Paulo: Artmed, 2012.

UNIVERSIDADE FEDERAL DE SÃO PAULO (Unifesp). Biotecnologia. O que é Biotecnologia. São José dos Campos, 2012. Disponível em: <http://www.sjc.unifesp. br/biotec_ict/?page_id=46>.

VALÉRIO, M.; BAZZO, W. A. O papel da divulgação científica em nossa sociedade de risco: em prol de uma nova ordem de relações entre ciência, tecnologia e sociedade. Revista de Ensino de Engenharia, v. 25, n. 1, p. 31-39, 2006.

VÁZQUEZ-ALONSO, A. et al. Consensos sobre a natureza da ciência: a ciência e a tecnologia na sociedade. Química Nova na Escola, v. 27, n. 27, p. 34-50, 2008.

YENER, Y.; ÖZKADIF, S. The suggested metaphors regarding on the concept of "cell" by teacher candidates of biology, science and primary. Procedia Social and Behavioral Sciences, v. 2, n. 2, p. 1.107-1.113, 2010. 